\title{
An Analysis of the Ecophysiological Adaptation of Tobacco Plant to a Limited Water Supply
}

\author{
by Tsumugu TotsukA* and Masami Monsi*
}

Received February 6, 1964

Mesophytes whose sound growth is promised under mesic conditions, suffer more or less the growth depression under a condition of limited water supply, although xerophytes can grow normally even under such a condition. This difference of the growth between mesophytes and xerophytes is generally ascribed to the difference in adaptability of the plants to the shortage of soil water, i. e. drought tolerance. Drought tolerance of plants is, however, a very complex character. Many workers have discussed it with various aspects ${ }^{1)}$; some with reference to morphological changes of plants exposed to drought, and others from the view point of changes in physiological characters, especially concerning hydrature of leaves ${ }^{2-4}$. However, there have been few analytical investigations as to how mesophytic plants can produce dry matter under a limited soil water condition.

The intensity of drought tolerance of some plants has been discussed on the basis of the water requirement ${ }^{5}$ ) or transpiration efficiency, a reciprocal of the former, and of the ratio of photosynthesis to transpiration rate of a single leaf ${ }^{6}$. In this paper an analysis of the factors affecting transpiration efficiency is made to clarify quantitatively the drought tolerance or ecophysiological adaptation of tobacco plants that were grown with limited water supply and suffered from wilting of their leaves.

\section{Plant growth with a limited water supply}

Nicotiana tabacum, "Bright Yellow" was used as a meterial. Thirty-seven-dayold plants grown under a controlled environmental condition and selected, were transplanted in enameled pots of $11 \mathrm{~cm}$ in diameter, $12 \mathrm{~cm}$ in height. The plant density was 1,2 and 4 individuals per pot. The pots were filled with a mixture of loamy soil and vermiculite $(1: 2), 5 \mathrm{~g}$ synthetic fertilizers $(\mathrm{N}: \mathrm{P}: \mathrm{K}=15: 15: 10)$ per pot being given initially. The mixture had its field capacity of $65 \%$ and permanent wilting point of $30 \%$ on an oven-dry weight basis, and it was watered at transplanting to obtain its field capacity or more. The experiment was started 7 days after the transplanting with the soil moisture of $85 \%$, and continued for 28 days. The plants were grown in a growth cabinet under a condition of continuous illumination of 4000 lux (ten 40 -watt fluorescent tubes, Toshiba white), $29^{\circ} \pm 1^{\circ}$, relative humidity of $64 \%$ $\left(11 \mathrm{mmHg}\right.$ in saturation deficit), and $0.035 \mathrm{CO}_{2}$ vol. $\%$. The plants grew normally under the condition, and enough space between the pots avoided the mutual shading. A half number of the pots were not watered for 10 days after starting the experiment to allow the plants to wilt. The second watering on the 11th day returned the soil moisture to $85 \%$. After that no water was supplied. The control plants were watered

A part of expense was supported by a Grant in Aid of Scientific Research of Ministry of Education.

* Department of Botany, Faculty of Science, University of Tokyo, Tokyo, Japan. 
every 3 or 4 days to maintain the soil moisture to be near the field capacity throughout the experiment. The moist-control set and the dry-treated one with different densities were respectively designated as $\mathrm{M}_{1}, \mathrm{M}_{2}, \mathrm{M}_{4}$ and $\mathrm{D}_{1}, \mathrm{D}_{2}, \mathrm{D}_{4}$. Samplings of the plants were made on the 10th, 20th and 28th day after starting the experiment. Fresh and dry weights of leaves, stems including petioles, and roots, and leaf area were determined with the plants of 2 pots in each set.

Dry weight growth was significantly affected by a shortage of soil moisture. Although for the first 10 days no clear difference was observed between the $M$ and $\mathrm{D}$ sets in dry weight growth of individual plants (Table 1 and Fig. 1), the difference became more remarkable with progress of the time, especially in denser pots. The plant dry weight was more or less equal at the start, attained at the second sampling on the 20th day to 0.93 , 0.71 and $0.59 \mathrm{~g}$ in the $\mathrm{M}_{1}, \mathrm{M}_{2}$ and $\mathrm{M}_{4}$ plots, and $0.79,0.54$ and $0.35 \mathrm{~g}$ in the $\mathrm{D}_{1}, \mathrm{D}_{2}$ and $\mathrm{D}_{4}$ plots: the latter corresponded respectively in the relative value to 0.85 , 0.77 and 0.59 for former. After the second sampling the treated plants ceased their growth almost entirely, and so the dry weight of the $\mathrm{D}_{1}, \mathrm{D}_{2}$ and $\mathrm{D}_{4}$ plants at the final sampling on the 28th day was almost the same as that at the second sampling, i. e. $0.80,0.55$ and $0.35 \mathrm{~g}$ respectively, while in the $\mathrm{M}_{1}, \mathrm{M}_{2}$ and $\mathrm{M}_{4}$ plants the dry weight was $2.6(+180 \%$ for the plant dry weight at the second sampling), $1.6(+125 \%)$ and $1.1 \mathrm{~g}(+85 \%)$. Such growth difference between the $\mathrm{M}$ and $\mathrm{D}$ sets could be demonstrated with the relative growth rates (RGR, $\mathrm{mg} / \mathrm{mg} /$ day) which were calculated with the data mentioned above (Fig. 2). The RGR of the dry-treated plants fell to zero in the later stage of the experiment, and this may be ascribed to the soil moisture which dropped below the wilting point, as will be discussed in the following section.

The leaf area growth per pot indicated a parallel change with the growth of total dry weight (see also Table 1). The relative

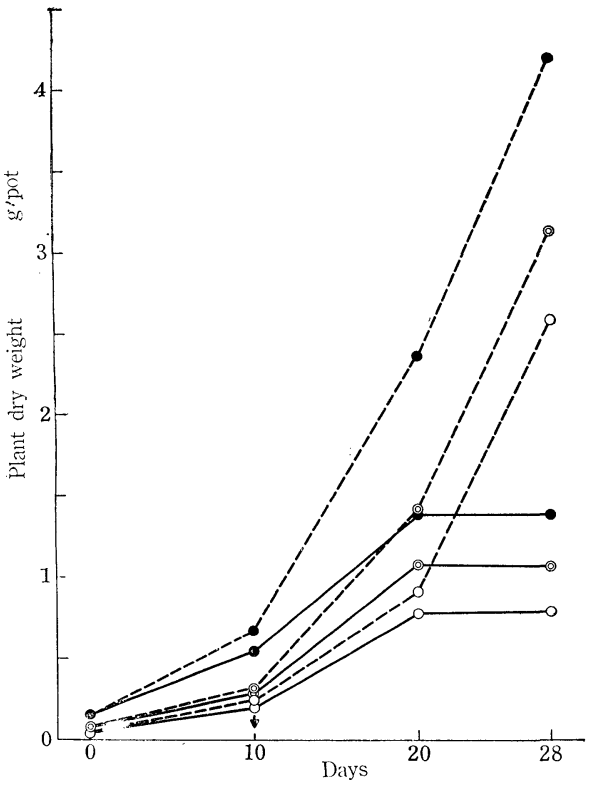

Fig. 1. Dry weight growth of tobacco plants in the moist-control set (broken lines) and the dry-treated set (continuous lines). Abscissa is the days after starting of the experiment. In a growth cabinet, continuous illumination of $4000 \mathrm{lux}$, and $29^{\circ}$. Planting densities were $1(\bigcirc), 2$ (○) and 4 (O) plant(s) per pot. Arrow indicates the day of the second watering in the dry set. Soil moisture in Fig. 3 .

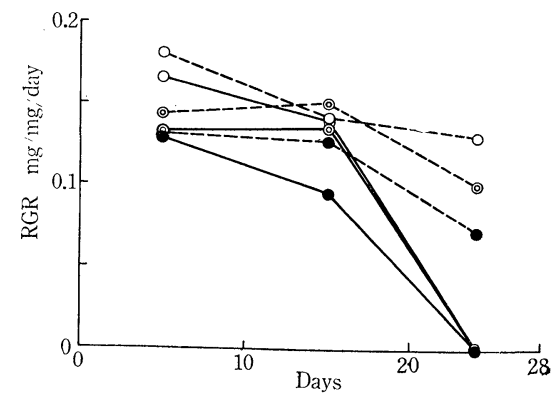

Fig. 2. Relative growth rates (RGR) in the moist set and the dry set. Indications as in Fig. 1. 
Table 1. Dry weight of leaves, stems + petioles and roots, and leaf area per pot of the tobacco plants in the moist set (M) and the dry set (D). Planting densities 1,2 and 4 individual(s)pot. Second watering of the dry set was made on the 11 th day. In a growth cabinet, continuous illumination of $4000 \mathrm{lux}, 29^{\circ}$ and $64 \%$ relative humidity.

\begin{tabular}{|c|c|c|c|c|c|c|c|c|c|c|}
\hline \multirow[b]{2}{*}{ Sets } & \multicolumn{5}{|c|}{ At the start } & \multicolumn{5}{|c|}{ On the 10 th day } \\
\hline & $\begin{array}{l}\text { Le } \\
\text { d. w } \\
\text { mg }\end{array}$ & $\begin{array}{l}\text { aves } \\
\text { area } \\
\mathrm{cm}^{2}\end{array}$ & $\begin{array}{l}\text { Stems \& } \\
\text { petioles } \\
\text { mg }\end{array}$ & $\begin{array}{c}\text { Roots } \\
\mathrm{mg}\end{array}$ & $\begin{array}{c}\text { Total } \\
\text { mg }\end{array}$ & $\begin{array}{l}\text { Le } \\
\text { d. w. } \\
\text { mg }\end{array}$ & $\begin{array}{l}\text { aves } \\
\text { area } \\
\mathrm{cm}^{2}\end{array}$ & $\begin{array}{l}\text { Stems \& } \\
\text { petioles } \\
\text { mg }\end{array}$ & $\begin{array}{c}\text { Roots } \\
\mathrm{mg}\end{array}$ & $\begin{array}{c}\text { Total } \\
\mathrm{mg}\end{array}$ \\
\hline $\mathrm{M}_{1}$ & 25.3 & 25.6 & 5.4 & 6.9 & 37.6 & 169 & 128.0 & 31 & 27 & 227 \\
\hline $\mathrm{M}_{2}$ & 50.6 & 51.2 & 10.8 & 13.8 & 75.2 & 239 & 168.7 & 40 & 36 & 315 \\
\hline $\mathrm{M}_{4}$ & 101.2 & 102.4 & 21.6 & 27.6 & 150.4 & 495 & 355.9 & 112 & 62 & 669 \\
\hline $\mathrm{D}_{1}$ & 25.3 & 25.6 & 5.4 & 6.9 & 37.6 & 143 & 86.7 & 25 & 24 & 195 \\
\hline $\mathrm{D}_{2}$ & 50.6 & 51.2 & 10.8 & 13.4 & 75.2 & 204 & 132.3 & 37 & 41 & 282 \\
\hline \multirow[t]{3}{*}{$\mathrm{D}_{4}$} & 101.2 & 102.4 & 21.6 & 27.6 & 150.4 & 384 & 270.4 & 82 & 79 & 544 \\
\hline & \multicolumn{5}{|c|}{ On the 20th day } & \multicolumn{5}{|c|}{ On the 28th day } \\
\hline & $\mathrm{mg}$ & $\mathrm{cm}^{2}$ & $\mathrm{mg}$ & $\mathrm{mg}$ & $\mathrm{mg}$ & $\mathrm{g}$ & $\mathrm{cm}^{2}$ & $\mathrm{~g}$ & $\mathrm{~g}$ & $\mathrm{~g}$ \\
\hline $\mathrm{M}_{1}$ & 683 & 434.5 & 155 & 79 & 927 & 1.72 & 868.5 & 0.51 & 0.36 & 2.59 \\
\hline $\mathrm{M}_{2}$ & 1019 & 645.5 & 257 & 138 & 1414 & 2.04 & 1085.0 & 0.68 & 0.41 & 3.13 \\
\hline $\mathrm{M}_{4}$ & 1668 & 1060.0 & 453 & 249 & 2369 & 2.78 & 1140.0 & 0.90 & 0.50 & 4.18 \\
\hline $\mathrm{D}_{1}$ & 571 & 279.5 & 122 & 94 & 787 & 0.52 & 268.0 & 0.16 & 0.11 & 0.79 \\
\hline $\mathrm{D}_{2}$ & 755 & 380.0 & 193 & 133 & 1081 & 0.72 & 345.5 & 0.19 & 0.16 & 1.07 \\
\hline $\mathrm{D}_{4}$ & 964 & 455.0 & 262 & 163 & 1386 & 0.94 & 429.0 & 0.26 & 0.18 & 1.38 \\
\hline
\end{tabular}

values at the final sampling were, if $\mathrm{M}_{1}=100 \%, \mathrm{M}_{2} 125 \%$ and $\mathrm{M}_{4} 131 \%$, and $\mathrm{D}_{1} 31 \%$, $\mathrm{D}_{2} 40 \%$ and $\mathrm{D}_{4} 49 \%$. Because of drying of fresh leaves the leaf area at the final sampling of the dry-treated plants became somewhat smaller than that at the second sampling.

\section{Water consumption and transpiration efficiency}

Water consumption of the pot, i.e. the total sum of the transpiration and soil surface evaporation, was determined throughout the experimental period by measuring loss in weight of the pot as a whole (Table 2). The soil-surface evaporation of the pot with the plant(s) was calculated as a difference between the total water consumption and the transpiration of the plant(s). As shown in Table 3, the soil-surface evaporation

Table 2. Mean water consumption in g/pot/day of the potted tobacco plant.

\begin{tabular}{c|c|c|c|r|r|r}
\hline \multirow{2}{*}{$\begin{array}{c}\text { Period of } \\
\text { measurement }\end{array}$} & \multicolumn{3}{|c|}{ Moist set } & \multicolumn{3}{|c}{ Dry set } \\
\cline { 2 - 7 } & $\mathrm{M}_{1}$ & $\mathrm{M}_{2}$ & $\mathrm{M}_{4}$ & $\mathrm{D}_{1}$ & $\mathrm{D}_{2}$ & $\mathrm{D}_{4}$ \\
\hline 0-10 days & 63.0 & 68.5 & 69.9 & 53.8 & 56.3 & 61.0 \\
$10-20$ days & 74.4 & 107 & 147 & 61.6 & 57.5 & 55.9 \\
$20-28$ days & 253 & 212 & 264 & 6.0 & 6.1 & 2.8 \\
\hline
\end{tabular}


Table 3. Soil surface evaporation (S) of the pot with plant covers in the moist set (M) and the dry set (D). Calculated as a difference between total water consumption (W) and transpiration (T). Mean values expressed as $\mathrm{g} / \mathrm{pot} / \mathrm{day}$.

\begin{tabular}{c|c|c|c|c|c|c|c|c|c}
\hline \multirow{2}{*}{$\begin{array}{c}\text { Period of } \\
\text { measurement }\end{array}$} & \multicolumn{3}{|c|}{ 6th-9th day } & \multicolumn{3}{c|}{ 11th-12th day } & \multicolumn{3}{|c}{ 18th day } \\
\cline { 2 - 10 } & $\mathrm{W}$ & $\mathrm{T}$ & $\mathrm{S}$ & $\mathrm{W}$ & $\mathrm{T}$ & $\mathrm{S}$ & $\mathrm{W}$ & $\mathrm{T}$ & $\mathrm{S}$ \\
\hline Sets & 21.4 & 10.2 & 11.2 & 24.5 & 18.0 & 6.5 & 65.2 & 58.3 & 6.9 \\
$\mathrm{M}_{1}$ & 33.7 & 15.5 & 18.2 & 35.7 & 28.0 & 7.7 & 66.9 & 60.9 & 6.0 \\
$\mathrm{M}_{2}$ & 41.5 & 31.3 & 10.2 & 44.8 & 41.5 & 3.3 & 99.8 & 86.5 & 13.3 \\
$\mathrm{M}_{4}$ & 21.1 & 7.8 & 13.3 & 23.5 & 14.0 & 9.5 & 26.5 & 15.4 & 11.1 \\
$\mathrm{D}_{1}$ & 20.3 & 9.3 & 11.0 & 26.2 & 16.0 & 10.2 & 24.4 & 11.1 & 13.3 \\
$\mathrm{D}_{2}$ & - & - & - & 37.0 & 27.0 & 10.0 & 18.0 & 12.0 & 6.0 \\
$\mathrm{D}_{4}$ & - &
\end{tabular}

was somewhat larger in the early stage of the experiment in any density plot, decreasing slightly with increase of leaf area, though some exceptions were seen. There could not be observed any distinct effect of planting density and of the drying treatment of the soil on the soil-surface evaporation. The comparison between Tables 2 and 3 may reveal that the soil water was consumed mainly by the transpiration of the plant(s), as discussed before ${ }^{7}$.

In the moist-control set the water consumption from the pot increased remarkably in parallel with the plant growth. However, in the treated set the consumption maintained an almost constant value for 20 days after the starting of the experiment, irrespective of the planting density, and afterwards it decreased strikingly to a very low value.

Soil moisture content was determined with soil samples from the center of the pot, since its vertical change was slight. Fig. 3 illustrated the obtained results. The soil moisture content in the $\mathrm{D}$ set decreased for the first 10 days almost linearly with the lapse of time, and with slight difference of the value among the pots with different plant densities. In the dry-treated plants, temporary wilting developed with the depression of soil moisture. The second watering on the 11th day returned the soil moisture to ca. $85 \%$, and the plants recovered turgescence in 2 hours. The soil moisture again decreased linearly to attain near wilting point of $30 \%$ in 10 days in the $\mathrm{D}_{4}$ pot, and in 12 days in the $\mathrm{D}_{1}$ pot.

Relationships between dry-matter production and drought tolerance were investigated with data obtained for 20 days of the experiment or under the condition where the soil moisture remained above the wilting point. The transpiration efficiency, mg drymatter increment per $g$ water consumed by

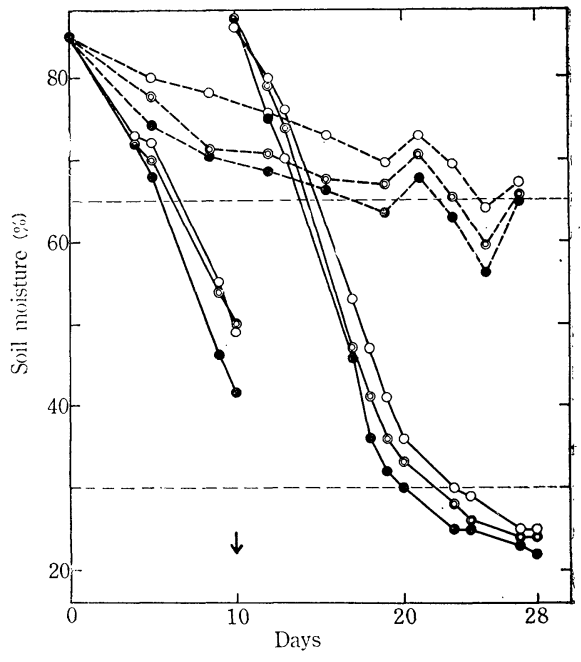

Fig. 3. Variations with time of the soil moisture content. Arrow indicates the day of the second watering in the dry set. Upper and lower thin broken lines indicate respectively level of the field capacity $(65 \%)$ and the permanent wilting point (30\%). 
plants which was proposed after Maximov ${ }^{8)}$, indicated for the first 10 days almost the same value between the $\mathrm{M}$ and the $\mathrm{D}$ set, as shown in Table 4. The large value in

Table 4. Transpiration efficiency in $\mathrm{mg} \mathrm{d.w./g}$ water of the potted tobacco plant. Calculated by the data of Tables 1 and 2 .

\begin{tabular}{c|c|c|c|c|c|c}
\hline \multirow{2}{*}{$\begin{array}{c}\text { Period of } \\
\text { measurement }\end{array}$} & \multicolumn{3}{|c|}{ Moist set } & \multicolumn{3}{c}{ Dry set } \\
\cline { 2 - 7 } & $\mathrm{M}_{1}$ & $\mathrm{M}_{2}$ & $\mathrm{M}_{4}$ & $\mathrm{D}_{1}$ & $\mathrm{D}_{2}$ & $\mathrm{D}_{4}$ \\
\hline 0-10 days & 0.33 & 0.35 & 0.74 & 0.29 & 0.37 & 0.65 \\
$10-20$ days & 0.91 & 1.03 & 1.16 & 0.96 & 1.39 & 1.52 \\
$20-28$ days & 0.65 & 0.77 & 1.02 & 0.65 & 0.88 & 1.06 \\
\hline
\end{tabular}

the $\mathrm{M}_{4}$ and $\mathrm{D}_{4}$ pots may suggest an effect of planting density on total transpiration. For the second 10 days, however, the dry-treated plants showed higher transpiration efficiency than the moist-control plants, and the difference was large in the denser pots. These facts demonstrate that the plants which were suffering from the shortage of soil moisture could utilize more effectively the soil moisture to produce dry matter than the moist plants ${ }^{9-12)}$, and that the dry plants became more tolerant of drought than the moist plants. Analytical discussions will be made in the following section for the sake of clarification of the increase of transpiration efficiency of tobacco plants by a limited water supply. This may give some quantitative elucidation of adaptability of plants to drought conditions.

\section{Analytical discussions of the transpiration efficiency}

Transpiration efficiency of a plant is a ratio of dry-matter increment to water consumption in a given period ${ }^{8}$. The dry-matter increment of the plant $(\Delta W)$ is the balance between the total photosynthate and total respiration loss ${ }^{13)}$. Total water consumption $(T)$ is the sum total of transpiration and soil-surface evaporation. Therefore, the transpiration efficiency $(E)$ is given by the following equation, which is similar to that already proposed by Totsuka ${ }^{7)}$ :

$$
E=\frac{\Delta W}{T}=\frac{q \cdot \bar{F}-r \cdot C}{T_{F} \cdot \bar{F}+T_{C} \cdot C_{H}+V}=\frac{q-r \cdot C / \bar{F}}{T_{F}+T_{C} \cdot C_{H} / \bar{F}+V / \bar{F}}
$$

where $\bar{F}$ is leaf area; $q$, net photosynthesis per unit leaf area; $r$, respiration rate of non-photosynthetic system; $C$, weight of non-photosynthetic systems (stems, petioles, and roots); $T_{F}$, leaf transpiration rate; $T_{C}$, transpiration rate of stems + petioles; $C_{H}$, weight of stems + petioles; $V$, soil-surface evaporation from the ground area occupied by the plant(s). Some of the components of this equation, $C / \bar{F}, C_{H} / \bar{F}$ and $T_{F}$, will be discussed in the following.

a) $C / \bar{F}$ and $C_{H} / \bar{F}$ : Table 5 shows the fresh weight of each organ in non-photosynthetic system of the plants at each sampling. Total fresh weight of non-photosynthetic system of the moist plants increased 20 days after starting the experiment to almost double of that of the dry plants of corresponding densities. However, $C / \bar{F}$ value of both sets was almost the same, though the high density pots indicated somewhat higher $C / \bar{F}$ values. The values of $C_{H} / \bar{F}$ were smaller in the $\mathrm{D}$ set than in the $\mathrm{M}$ set, because the limited water supply suppressed the growth of stems and petioles more 
Table 5. Stems + petioles and roots (tap and lateral) in fresh weight $\mathrm{g} / \mathrm{pot}, C / \bar{F}$ (g fresh weight of non-photosynthetic systems per $\mathrm{cm}^{2}$ leaf area), and $C_{\boldsymbol{H}} / \bar{F}$ (g fresh weight of stems + petioles per $\mathrm{cm}^{2}$ leaf area) in the moist set (M) and the dry set (D).

\begin{tabular}{|c|c|c|c|c|c|c|c|c|c|c|c|c|c|c|c|}
\hline \multirow{3}{*}{ Sets } & \multicolumn{5}{|c|}{ At the start } & \multicolumn{5}{|c|}{ On the 10th day } & \multicolumn{5}{|c|}{ On the 20th day } \\
\hline & \multirow{2}{*}{$\begin{array}{l}\text { Stems + } \\
\text { petioles }\end{array}$} & \multicolumn{2}{|c|}{ Roots } & \multirow{2}{*}{$C / \bar{F}$} & \multirow{2}{*}{$C_{H} / \bar{F}$} & \multirow{2}{*}{$\begin{array}{l}\text { Stems + } \\
\text { petioles }\end{array}$} & \multicolumn{2}{|c|}{ Roots } & \multirow{2}{*}{$C / \bar{F}$} & \multirow{2}{*}{$C_{H} / \bar{F}$} & \multirow{2}{*}{$\begin{array}{l}\text { Stems + } \\
\text { petioles }\end{array}$} & \multicolumn{2}{|c|}{ Roots } & \multirow{2}{*}{$C / \bar{F}$} & \multirow{2}{*}{$C_{H} / \bar{F}$} \\
\hline & & $\operatorname{tap}$ & lateral & & & & $\operatorname{tap} 1$ & lateral & & & & $\operatorname{tap} \mid 1$ & lateral & & \\
\hline $\mathrm{M}_{1}$ & 0.12 & 0 & 0.05 & 6.7 & 4.7 & 0.69 & 0.05 & 0.34 & 8.5 & 5.4 & 2.82 & $0.20 \mid$ & 0.96 & 9.2 & 6.5 \\
\hline $\mathrm{M}_{2}$ & 0.24 & 0 & 0.10 & " & " & 0.82 & 0.02 & 0.45 & 7.6 & 4.9 & 4.36 & 0.27 & 1.53 & 9.5 & 6.8 \\
\hline $\mathrm{M}_{4}$ & 0.48 & 0 & 0.20 & " & " & 2.31 & 0.09 & 0.90 & 9.3 & 6.5 & 7.30 & 0.46 & 2.82 & 10.0 & 6.9 \\
\hline $\mathrm{D}_{1}$ & 0.12 & 0 & 0.05 & " & "I & 0.39 & 0.02 & 0.34 & 8.6 & 4.5 & 1.53 & 0.13 & 1.09 & 9.8 & 5.5 \\
\hline $\mathrm{D}_{2}$ & 0.24 & 0 & 0.10 & " & " & 0.54 & 0.04 & 0.54 & 8.6 & 4.1 & 2.32 & 0.25 & $1.35^{\circ}$ & 10.3 & 6.1 \\
\hline $\mathrm{D}_{4}$ & 0.48 & 0 & 0.20 & " & " & 1.18 & 0.05 & 0.90 & 7.9 & 4.4 & 2.90 & 0.27 & 1.65 & 10.6 & 6.4 \\
\hline
\end{tabular}

heavily than the growth of roots and leaves. As seen in the above-mentioned equation, the decrease of $C / \bar{F}$ and $C_{H} / \bar{F}$ values can induce the increase of transpiration efficiency. Therefore, the increase of the transpiration efficiency in the D plants should result from the decrease of the $C_{H} / \bar{F}$ value, since the $C / \bar{F}$ decrease of these plants was not brought about by the limitation of water supply.
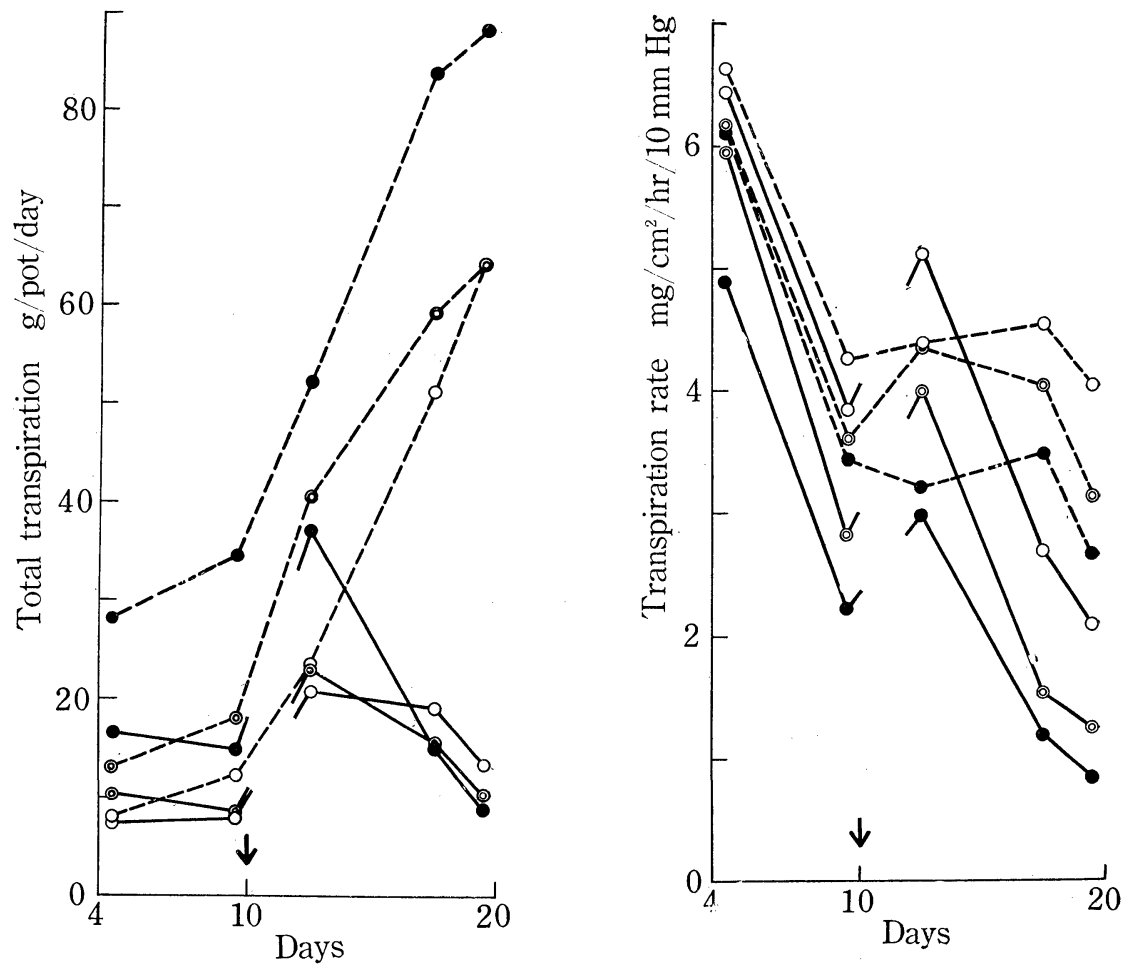

Figs. 4 (left) and 5 (right). Total transpiration per pot (left) and transpiration rate of a leaf (right) in the moist and the dry sets. Arrow indicates the day of the second watering in the dry set. Indications as in Fig. 1. 
b) $T_{F}$ : Changes of the total transpiration from the pot were pursued, as shown in Fig. 4, by measuring the weight loss of the pot covered its soil surface with vinyl film. In the $M$ set, the daily transpiration per pot was increased generally in parallel with the increase of the leaf area. In the $\mathrm{D}$ set, the transpiration amount was slightly less on the 10th day of the experiment than on the 4 th day, but it increased rapidly after the second watering. The increased transpiration, however, was again depressed with the decrease of soil moisture that reached nearly the wilting point on the 20th day.

The transpiration rate per unit leaf area, $T_{F}$, was calculated from the data in Table 1 and Fig. 4, and its difference between the $M$ and the $D$ set was illustrated in Fig. 5. The first depression of transpiration rate not only in the $\mathrm{D}$ set but also in the $M$ set might be mainly caused by some effects of the enlargement of each transpiring area and of the plant density. The transpiration rate in the $M$ set showed rather in general stable values. In the $\mathrm{D}$ set, a recovery of the transpiration rate was observed after the second watering. Afterwards, however, the successive drying of the soils induced a rapid reduction of the leaf transpiration rate. It may be conclusive that this reduction of the transpiration rate has, as generally suggested, a major effect on the increase of transpiration efficiency of a plant exposed to drought.

c) Factors affecting photosynthetic rate: In order to clarify the effect of soil moisture deficiency on the photosynthetic activity, net assimilation rate (NAR, mg d. w. $/ \mathrm{dm}^{2} /$ day) was calculated by a method reported in a previous paper ${ }^{14)}$. The obtained values were as follows;

\begin{tabular}{lrrrrrc} 
& \multicolumn{3}{c}{ Control } & \multicolumn{3}{c}{ Treated } \\
& $\mathrm{M}_{1}$ & $\mathrm{M}_{2}$ & $\mathrm{M}_{4}$ & $\mathrm{D}_{1}$ & $\mathrm{D}_{2}$ & $\mathrm{D}_{4}$ \\
For the first 10 days & 0.74 & 0.47 & 0.51 & 0.62 & 0.40 & 0.38 \\
For the second 10 days & 0.55 & 0.65 & 0.48 & 0.68 & 0.60 & 0.31
\end{tabular}

Although the NARs of the $\mathrm{D}_{4}$ plants were smaller than those of the corresponding $\mathrm{M}_{4}$ plants, no clear difference between the NARs of both sets was observed. In other words, the treated plants could maintain a certain high value of NAR, suffering from heavy depression of soil moisture content. The observed fact that the soil water shortage had only a slight effect on the NARs may accord with the report of some workers ${ }^{15-17)}$.

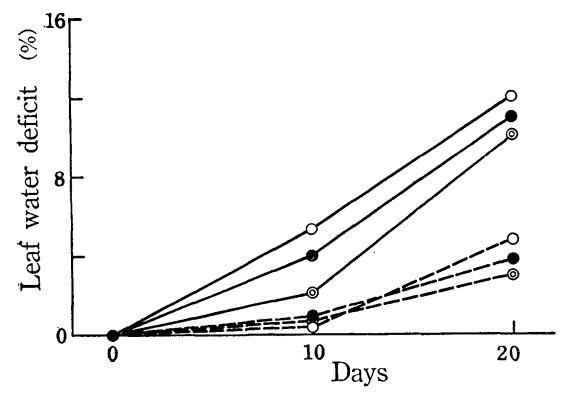

Fig. 6. Leaf water deficit in $\%$ of a saturated water content. Indications as in Fig. 1.
It is generally believed that the leaf water deficit could cause the decrease of photosynthetic rate of leaves ${ }^{14,18-25)}$. In the leaves of tobacco plants which were limited in water supply, marked wilting was observed during the experimental period. The leaf water deficit ${ }^{26)}$ increased successively in the dry-treated plants, especially of the dense pot, while no serious deficit was observed in the moist-control ones (Fig. 6). The NARs of the treated plants, as mentioned above, slightly differed from those of the control, and this indicated that the photosynthetic rate per unit leaf area might be to some extent 
irrespective of the shortage of soil moisture. Simonis ${ }^{22)}$ has already reported that the photosynthetic rate and the leaf dry weight per unit area were somewhat larger in Trifolium grown on dry soils than in that grown on moist soils.

The leaf water deficit can mainly be determined, as already discussed in a previous paper ${ }^{26)}$, by the active root/leaf area ratio $\left(C_{w} / \bar{F}\right.$ ratio) and the transpiration rate of a leaf. With special reference to these values, factors which relate the increase of the leaf water deficit were investigated. Fig. 7 shows the changes of the $C_{w} / \bar{F}$ ratio calculated by the data of lateral roots (Table 4 ) and leaf area (Table 1$)$. The $C_{w} / \bar{F}$ ratio in the drytreated plants increased remarkably for the first 10 days, though that in the moist-control changed in a narrow range. The high $C_{w} / \bar{F}$ ratio of the treated plants must lower the leaf water deficit, provided that the transpiration rate and the ability of water absorption of roots are unchanged.

Even in the case of the same $C_{w} / \bar{F}$ ratio, the root surface per unit fresh weight of roots can increase with decrease of the diameter of $\operatorname{roots}^{26)}$. Diameters of about 400 fine roots were measured on the 10th day. The mean diameters were in the $\mathrm{M}_{1}, \mathrm{M}_{2}$ and $\mathrm{M}_{4}$ plants $0.28,0.30$ and $0.29 \mathrm{~mm}$, respectively. The relative value of the root diameter in the $D_{1}, D_{2}$ and $D_{4}$ plants was respectively $1.01,0.88$ and 0.94 of that of the control plants. Such a slight decrease, in general, of root diameter of the treated plants may act favorably for the water economy of the plants through the increase of water absorbing surface of the roots.

The leaf dry matter index, i. e. dry matter in $\mathrm{mg}$ per leaf area in $\mathrm{cm}^{2}$, being an index for leaf thickness, is also a factor influencing the photosynthetic rate ${ }^{22,27)}$. This index increased in parallel with the leaf water deficit (see Fig. 8), and was larger in the treated plants than in the control ones. This suggests that the leaf water deficit may suppress the leaf growth in area, and that the thickness of leaves may diminish the decrease of photosynthetic rate of leaves caused by with increasing leaf water deficit. The facts reported by Simonis ${ }^{22}$ demonstrate the above-mentioned suggestions.

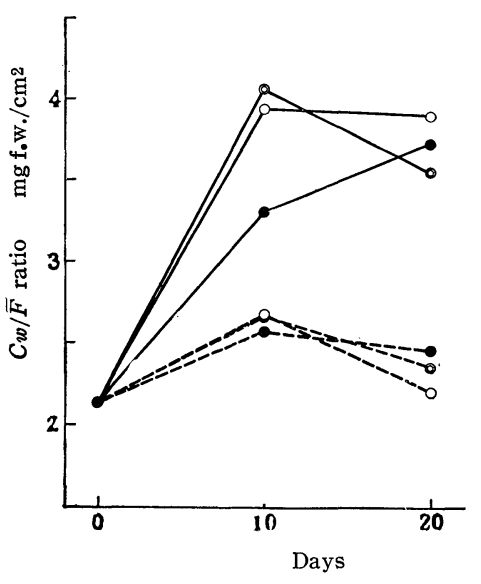

Fig. 7. Ratio of fresh weight of lateral root to leaf area $\left(C_{w} / \bar{F}\right.$ ratio). Indications as in Fig. 1.

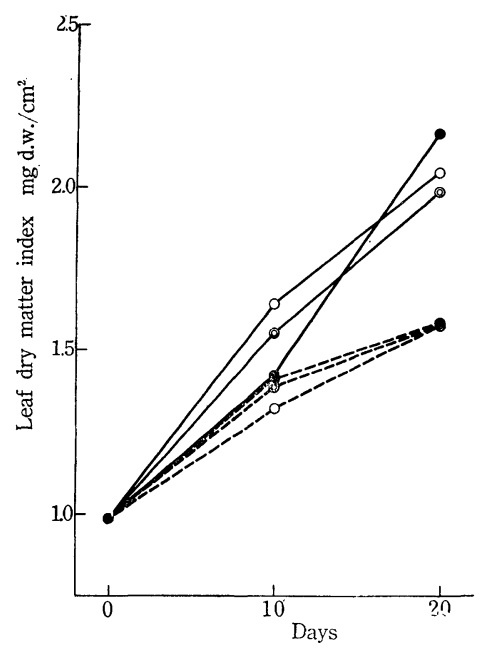

Fig. 8. Leaf dry matter index which shows the thickness of leaves. Indications as in Fig. 1.

Respiration rate of non-photosynthetic systems and transpiration rate of stems and petioles should take part in the changes of transpiration efficiency, as seen in the equation. As to the effect of the changes of water content of stems and petioles on the transpiration rates and respiratory activities of these organs no observations were 
made. These problems remain for further investigations.

In conclusion, it can be said that the drought tolerance of plants grown under a limited water supply can be increased by the following changes of their ecophysiological characters which determine the utilization of soil moisture to dry-matter production; smallness of transpiration rate of the leaf, fresh weight of stems + petioles per unit leaf area, and suppression of the increase of leaf water deficit by increase of the fresh weight of active roots per unit leaf area and by decrease of the diameter of the roots. Thickening of leaves also compensates the decrease of photosynthetic rate.

\section{Summary}

Analytical studies of a transpiration efficiency were made to clarify the ecophysiological adaptability of potted tobacco plants to a limited water supply.

1. Dry weight growth was significantly affected by soil moisture shortage. The relative growth rate (RGR) of the dry-treated plants decreased slightly in the early stage, but remarkably in the later stage. However, there was slight difference in the net assimilation rate (NAR) between the moist-control and dry-treated plants throughout the experiment.

2. Water consumption per pot was increased in the control set with increase of the plant weight and leaf area. In the treated plants the water consumption was limited clearly with transient wilting caused by the depression of soil moisture.

3. Leaf water deficit was more distinct in the treated plants than in the control plants, but this was slightly compensated by increase of fine roots and the increase of leaf dry matter index.

4. The active root/leaf area ratio $\left(C_{w} / \bar{F}\right.$ ratio) increased in the treated plants to about one and a half times than that of the control plants 10 days after starting the experiment. This increase is favorable for the water economy of the plant.

5. A similar transpiration efficiency was calculated for the first 10 days in the control and the treated plants, but the latter increased their transpiration efficiency for the second 10 days with depression of soil moisture. High plant density (4 plants per pot) gave also high transpiration efficiency.

6. An equation was formulated to analyze the transpiration efficiency, and the factors effective in increasing the efficiency of the dry-treated plants were discussed. The main factors were the decreased fresh weight of stems + petioles per unit leaf area $\left(C_{H} / \bar{F}\right)$ and the lowered transpiration rate of the leaf under the drought condition.

7. Drought tolerance of the tobacco plants to a limited water supply was strengthened by (a) low development of stems and petioles in comparison with leaf area, (b) low transpiration rate of the leaf, (c) increase of water absorbing area caused by decreasing diameter of fine roots, and (d) remarkable increase of leaf thickness which may reduce the depression of photosynthetic rate with compensating the leaf water deficit.

\section{References}

1) Russel, M. B., Advances in Agron. 11: 70 (1959). 2) Walter, H., Die Hydratur der Pflanze und ihre physiologisch-ökologische Bedeutung (Gustav Fischer Verlag, Jena, 1931). 3) Levitt, J., The Hardness of Plants (Academic Press, New York, 1956). 4) Iljin, W. S., Ann. Rev. Plant Physiol. 8: 257 (1957). 5) Briggs, L. J., and Shantz, H. L., U. S. Dept. Agric., Bur. 
Plant Ind. Bull. (1913). 6) Larcher, W., Bull. Res. Counc. Israel 8D: 213 (1960). 7) Totsuka, T., J. Fac. Sci. Univ. Tokyo III 8(9): 341 (1963). 8) Maximov, N. A., The Plant in Relation to Water (George Allen \& Unwin Ltd., London, 1927). 9) Koketsu, R., and Nagasawa, K., Bull. Sci. Fac. Tercul. Kjusu Imp. Univ. 7: 211 (1936). 10) Kelley, O. J., Advances in Agron. 6: 67 (1954). 11) Peters, D. B.. and Johnson, L. C., Agron. J. 52 (12): 687 (1960). 12) Takahashi, H., Matsubayashi, M., and Oizumi, H., Proc. Crop Sci. Soc. Jap. 30 (1): 47 (1961). 13) Iwaki, H., Jap. J. Bot. 16: 210 (1958). 14) Totsuka, T., and Monsi, M., Bot. Mag. Tokyo 72: 367 (1959). 15) Owen, P. C., and Watson, D. J., Nature 177: 847 (1956). 16) Owen, P. C., New Phytol. 57: 318 (1958). 17) Orchard, B., The Water Relations of Plant, 340 (Rutter, A. J., and Whitehead, F. H. Ed. Blackwell Sci. Publ., London, 1963). 18) Iljin, W. S., Flora 116: 360 (1923). 19) Bernbeck, O., ibid. 117: 293 (1924). 20) Dastur, R. H., and Desai, B. L., Ann. Bot. 47: 69 (1933). 21) Schneider, G. W., and Childers, N. F., Plant Physiol. 16: 565 (1941). 22) Simonis, W., Planta 35: 188 (1947). 23) Pisek, A., and Winkler, E., Protoplasma 46: 597 (1956). 24) Totsuka, T., Oshima, T., and Monsi, M., Bot. Mag. Tokyo 73: 389 (1960). 25) Iyama, J., and Murata, Y.. Proc. Crop Sci. Soc. Jap. 29 (3): 350 (1961). 26) Totsuka, T., and Monsi, M., Bot. Mag. Tokyo 73: 14 (1960). 27) Pieters, G. A., Meded. Landbouwhogeschool, Wageningen 60 (17): 1 (1960).

戸塚 績, 門司正三：土壤乾燥に対するタバコの適応性について

土㙥含水量低下に対するタバコの生態生理学的適応性を明らかにするために蒸散効率を解析した, 発 芽後 37 日目のタバコを栽植密度を変えて鉢植えし，4,000 lux の連続照射, 温度 $29^{\circ}$, 湿度 $64 \%, \mathrm{CO}_{2}$ 濃度 $0.035 \%$ もとで 28 日間栽培した。湿潤区 $(\mathrm{M})$ の鉢の土壌含水量は実験期間中ほぼ野外容水量 $(65 \%)$ に保っ

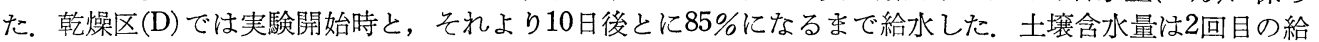
水上り10日後にほ涪永久し物れ点 (30\%) に達した。土壌水分が減少するにつれてD区では葉の水分久差が 高まり, 単位葉面積あたりの葉乾重が増加した。すた側根の直径がいくぶん減少した。相対生長率は実験 期間中 M 区ではあまり差がみられなかったが，D区では後期に著しく低下した。しかし純同化率は実騟 期間を通じて両区の間でほとんぞ差がみられなかった。実験開始後20日間の水消費量と乾物増加量とから 求めた蒸散效率は $\mathrm{D}$ 区の方が $\mathrm{M}$ 区より大きかった，蒸散効率に関する関係式をつくり，その要因を検討 した結果, 単位葉面積あたりの茥(葉柄を含む)の生量減少と葉の蒸散率の著しい低下が D区の蒸散效率を 高めた主な要因であった。

以上の結果, 水供給が制限された植物では葉の蒸散率が著しく低下し, 葉面積生長に比して地上部非 同化器官の生長が低下して植物体の水消費が抑制される。一方, 単位葉面積あたりの側根の生量が增加し, 側根の直径が減少して葉の水分欠差の增加が抑制される.ささらに単位葉面積あたりの葉の乾量の著しい增 加が葉の水欠乏による光合成能率の低下を軽減して, 耐乾燥性が高められると推論される。（東京大学理 学部植物学教室) 